\title{
Pulmonary function in healthy young adult Indians in Madras
}

\author{
V K Vijayan, K V Kuppurao, P Venkatesan, K Sankaran, R Prabhakar
}

\begin{abstract}
Forced vital capacity, forced expiratory volume in one second, functional residual capacity, residual volume, total lung capacity, and single breath diffusing capacity measurements (effective alveolar volume, carbon monoxide transfer factor, and transfer coefficient) were measured in 247 young healthy adults (130 male, 117 female) aged 15-40 years living in Madras. Subjects were of Dravidian stock, living at sea level with rice as their staple diet. Regression equations were derived for men and women for predicting normal pulmonary function for young adults in South India. The values were similar to those reported for subjects from Western India and lower than those reported for North Indians and caucasians.
\end{abstract}

Differences in pulmonary function in normal people may be due to ethnic origin, physical activity, environmental conditions, altitude, tobacco smoking, age, height, sex, and socioeconomic status. ${ }^{1}$ The wide range of geographical and climatic conditions in a large country such as India may be associated with regional differences in lung function in healthy individuals, as shown in previous studies. $^{2-6}$ We have measured pulmonary function, including spirometric indices, static lung volumes, and diffusing capacity indices, in healthy young adults in South India.

\section{Methods}

SUBJECTS

We studied 247 ethnic South Indians living in Madras and aged 15-40 years. They included relatives of patients attending the Tuberculosis Research Centre, staff members, manual workers, students, and executives, to obtain a cross section of the normal inhabitants of Madras city. The proportions of subjects in the different income groups were: low (less than 500 rupees a month) $49 \%$, middle (500-1500 rupees) $38 \%$, and high (more than 1500 rupees) $13 \%$, similar to the proportions seen in the general population in Madras city (data obtained from Madras Municipal Corporation on the basis of the 1981 government census). The proportion of subjects who declined to take part in this study was less than $1 \%$. Subjects were eligible for the study if they were ethnic South Indians, had no structural deformity of the thoracic cage, and were free from respiratory infections and had been so for at least three months before the tests. None of the subjects had any cardiorespiratory disease, as assessed by detailed history, physical examination, chest radiography, and 12 lead electrocardiography. Symptomless smokers were included.

\section{TESTS}

Pulmonary function tests were carried out with transfer test model C ( $P$ K Morgan, Chatham, UK), readings being obtained from a Data Dec computer. Sex, ethnic identity, standing height to the nearest centimetre without shoes, weight in kilograms, age, smoking habit, occupation, and spirometer temperature were recorded for all subjects before testing. The tests were carried out with the subject seated and with a nose clip applied. The equipment was calibrated fully every day. The coefficient of variation for six subjects studied over a year was less than $1 \%$ for forced vital capacity (FVC) and forced expiratory volume in one second $\left(\mathrm{FEV}_{1}\right)$, less than $2 \%$ for total lung capacity (TLC), alveolar volume (VA), carbon monoxide transfer factor (TLCO), and transfer coefficient (KCO), less than $2.5 \%$ for functional residual capacity (FRC), and less than $5 \%$ for residual volume (RV). All volumes were expressed in BTPS.

\section{Spirometry}

At least three forced vital capacity manoeuvres $^{7}$ were obtained for each subject; for FVC and $\mathrm{FEV}_{1}$ the best two of three tracings had to be within $\pm 5 \%$. The largest of three FVC and $\mathrm{FEV}_{1}$ values was accepted even if the two volumes did not come from the same curve. The ratio of $\mathrm{FEV}_{1}$ to FVC was expressed as a percentage.

\section{Static lung volumes}

Functional residual capacity, residual volume, and total lung capacity were measured by the closed circuit helium dilution method. ${ }^{8}$ Duplicate measurements of FRC were made for each patient and the mean value was used for analysis. ${ }^{1}$ Residual volume and total lung capacity were calculated from the kymograph tracing.

Single breath carbon monoxide transfer factor The single breath carbon monoxide transfer factor $^{78}$ was measured with a gas mixture containing helium $14 \%$, carbon monoxide $0.288 \%$, and oxygen $18 \%$, the rest being 
nitrogen (P K Morgan). All subjects attended the clinic at $0730-0800$ hours and the single breath measurements were performed after 1200 hours to make sure that none of the smokers had smoked tobacco for at least four hours before the test. This was performed at least in duplicate and values were accepted if the duplicate determinations did not vary by more than $5 \%$. The highest value (expressed in $\mathrm{mmol} / \mathrm{kPa} / \mathrm{min}$ ) was used for the analysis. A value for alveolar volume was obtained during the single breath TLCO measurement. Kco was calculated as the ratio of TLCo to VA and expressed in $\mathrm{mmol} / \mathrm{kPa} / \mathrm{min} /$ litre. Measured TLCo and Kco were corrected to a standard haemoglobin $(\mathrm{Hb})$ concentration of $14.6 \mathrm{~g} / \mathrm{dl}$ by means of the following equation':

TLCo corrected for $\mathrm{Hb}$ concentration (CTLCO) $=$

TLco observed $\times(14.6 \mathrm{a}+\mathrm{Hb}) /(1+\mathrm{a}) \mathrm{Hb}$,

where $\mathrm{Hb}$ is the actual haemoglobin concentration in $\mathrm{g} / \mathrm{dl}$ and $\mathrm{a}$ is $\mathbf{0 \cdot 7}$. The Kco corrected for haemoglobin (CKco) was calculated from CTLCo.

\section{STATISTICAL METHODS}

Best fitting cross sectional equations were derived separately for men and women by multiple linear regression analysis. As there was an increase in spirometric and static lung volumes from 15 to 25 years, a plateau from 25 to 35 years, and a decline from 35 years onwards, a quadratic term (age squared) was included in the prediction model. $\mathrm{Age}^{2}$ and height were entered into the equation for all pulmonary function measurements; age $^{2}$ height interactions were tested for significance by means of a stepwise regression procedure. Residuals were calculated and tested for each of these best fitting models for each sex. The goodness of fit of the models was also tested by examining the correlations of residuals with age ${ }^{2}$ and height and by inspecting graphs of residuals versus predicted values to confirm the absence of a curvilinear pattern. A dummy variable for smoking (non-smokers $=0$, smokers $=1$ ) was introduced into the regres- sion equations to test the effect of smoking in men.

All analyses were performed with the SPSS/PC statistical computing package on an IBM/XT compatible personal computer. Unless otherwise specified, the term significant is used to imply a $p$ value of less than $0 \cdot 05$.

\section{Results}

The mean (SD) height was $166(7 \cdot 6) \mathrm{cm}$ in men and $152(5.3) \mathrm{cm}$ in women, and weight was $53.4(11.6)$ and $44.7(9.3) \mathrm{kg}$. The mean haemoglobin concentration in men was 14.3 $(1 \cdot 7) \mathrm{g} / \mathrm{dl}$ and only two had values below $11 \mathrm{~g} / \mathrm{dl}$. In women, however, it was $10 \cdot 8$ $(1.6) \mathrm{g} / \mathrm{dl}$ and $27(23 \%)$ had a concentration of less than $10 \mathrm{~g} / \mathrm{dl}$. All women were non-smokers. Among the 45 male smokers eight had stopped smoking at least one year before the tests; 26 had smoked three to 10 cigarettes or bidis (sun cured tobacco packed loosely inside a vegetable leaf) a day for less than five years, and 11 had smoked more than 20 cigarettes or bidis a day for more than five years.

In men the mean FVC was $3.53(0.68)$ litres, TLC 4.76(0.86) 1 , and TLCo $9 \cdot 40(2 \cdot 00) \mathrm{mmol} /$ $\mathrm{kPa} / \mathrm{min}$; in women the mean FVC was 2.37 $(0.36) 1$, TLC $3.43(0.45) 1$, and TLCo 6.34 $(1 \cdot 10) \mathrm{mmol} / \mathrm{kPa} / \mathrm{min}$. Almost all measurements reached a peak in the 20-24 age group, remained at that level up to the age of 30-34 years, and then showed a mild decline. RV and $\mathrm{RV} / \mathrm{TLC} \%$, however, showed a small rise in the 35-40 year age group. $\mathrm{FEV}_{1} / \mathrm{FVC} \%$ showed a gradual decline with increasing age in both sexes. Additional data are available on request.

Both age and height in men showed a significant positive correlation with FVC, FRC, $\mathrm{RV}$, TLC and VA; the correlations were stronger with height (table 1). FEV $\mathrm{FV}_{1}$ and TLCo were significantly correlated with height; Kco showed a significant negative correlation with age. In women FVC, FEV, FRC, TLC, and VA showed a significant positive correlation with height (table 2). There was a negative

Table 1 Regression relationships for predicting indices of lung function from age $e^{2}(y)$ and height $(\mathrm{cm})$ in healthy young adult South Indian men

\begin{tabular}{|c|c|c|c|c|c|c|c|c|c|}
\hline \multirow[b]{2}{*}{ Measurement } & \multirow[b]{2}{*}{ Mean } & \multirow[b]{2}{*}{$S D$} & \multirow[b]{2}{*}{ Constant } & \multicolumn{2}{|c|}{ Regression coefficients $\dagger$} & \multirow[b]{2}{*}{ Multiple $R$} & \multirow{2}{*}{$\begin{array}{l}\text { Standard } \\
\text { error }\end{array}$} & \multicolumn{2}{|c|}{ Correlation coefficients } \\
\hline & & & & $A g e^{2}$ & Height & & & Age & Height \\
\hline $\begin{array}{l}\text { FVC } \\
\text { FEV }_{1}\end{array}$ & $\begin{array}{l}3.53 \\
3.02\end{array}$ & $\begin{array}{l}0.68 \\
0.60\end{array}$ & $\begin{array}{l}-6.857 \\
-6.195\end{array}$ & $\begin{array}{l}-0.00023 \\
-\end{array}$ & $\begin{array}{l}0.062 \\
0.057\end{array}$ & $\begin{array}{l}0.71 \\
0.72\end{array}$ & $\begin{array}{l}0.481 \\
0.415\end{array}$ & $\begin{array}{l}0.275^{\star} \\
0.120\end{array}$ & $\begin{array}{l}0.692^{\star \star} \\
0.650^{\star \star}\end{array}$ \\
\hline$\frac{\mathrm{FEV}_{\mathrm{L}}}{\mathrm{FVC}} \%$ & $85 \cdot 87$ & $7 \cdot 05$ & $76 \cdot 695$ & -0.00613 & 0.080 & 0.36 & 6.638 & $\begin{array}{c}0.129 \\
-0.355^{\star \star}\end{array}$ & -0.089 \\
\hline $\begin{array}{l}\text { FRC } \\
\text { RV } \\
\text { TLC } \\
\text { RV }\end{array}$ & $\begin{array}{l}2 \cdot 63 \\
1 \cdot 36 \\
4 \cdot 76\end{array}$ & $\begin{array}{l}0.61 \\
0.50 \\
0.86\end{array}$ & $\begin{array}{l}-5.341 \\
-3.596 \\
-8.267\end{array}$ & $\begin{array}{l}0.00035 \\
0.00043 \\
0.00060\end{array}$ & $\begin{array}{l}0.047 \\
0.028 \\
0.076\end{array}$ & $\begin{array}{l}0.65 \\
0.61 \\
0.76\end{array}$ & $\begin{array}{l}0.470 \\
0.399 \\
0.564\end{array}$ & $\begin{array}{l}0 \cdot 450^{\star \star} \\
0 \cdot 474^{\star \star} \\
0 \cdot 510^{\star \star}\end{array}$ & $\begin{array}{l}0.621^{\star \star} \\
0.533^{\star \star} \\
0.736^{\star \star}\end{array}$ \\
\hline$\frac{\mathrm{RV}}{\mathrm{TLC}} \%$ & $27 \cdot 82$ & 5.93 & $42 \cdot 492$ & 0.00777 & $-0 \cdot 127$ & 0.52 & $5 \cdot 117$ & $0.490^{\star \star}$ & 0.056 \\
\hline $\begin{array}{l}\text { VA } \\
\text { TLCo } \\
\text { Kco } \\
\text { CTLCo } \\
\text { CKCo }\end{array}$ & $\begin{array}{l}4 \cdot 37 \\
9 \cdot 40 \\
2 \cdot 17 \\
9 \cdot 15 \\
2 \cdot 13\end{array}$ & $\begin{array}{l}0.88 \\
2 \cdot 00 \\
0.38 \\
1 \cdot 69 \\
0 \cdot 32\end{array}$ & $\begin{array}{r}-6.870 \\
-11.236 \\
3.126 \\
-8.666 \\
3.658\end{array}$ & $\begin{array}{r}0.00062 \\
-0.00040 \\
-0.00014 \\
-0.00009 \\
-0.00023\end{array}$ & $\begin{array}{c}0.065 \\
0.126 \\
-0.005 \\
0.110 \\
-0.0075\end{array}$ & $\begin{array}{l}0.66 \\
0.48 \\
0.41 \\
0.45 \\
0.47\end{array}$ & $\begin{array}{l}0.664 \\
1.772 \\
0.347 \\
1.519 \\
0.286\end{array}$ & $\begin{array}{c}0 \cdot 474^{\star \star} \\
0 \cdot 222 \\
-0.259^{\star} \\
0 \cdot 178 \\
-0.434^{\star \star}\end{array}$ & $\begin{array}{c}0 \cdot 688^{\star \star} \\
0 \cdot 448^{\star \star} \\
-0 \cdot 247^{\star \star} \\
0 \cdot 439^{\star \star} \\
-0 \cdot 371^{\star \star}\end{array}$ \\
\hline
\end{tabular}

$\dagger$ Smoking coefficient for $\mathrm{KCO}=-0 \cdot 164$; smoking coefficient for $\mathrm{CKCO}=-0.217$.

${ }^{\star} \mathrm{p}<0.01 ;{ }^{\star \star} \mathrm{p}<0.001$

FVC — forced vital capacity; FEV — - forced expiratory volume in one second; FRC — functional residual capacity; RV-residual volume; TLC - total lung capacity; $\mathrm{VA}-$ alveolar volume; TLCO-carbon monoxide transfer factor; Kco-transfer coefficient. 
Table 2 Regression relationships for predicting indices of lung function from age ${ }^{2}(y)$ and height $(\mathrm{cm})$ in healthy young adult South Indian women (non-smokers)

\begin{tabular}{|c|c|c|c|c|c|c|c|c|c|}
\hline \multirow[b]{2}{*}{ Measurement } & \multirow[b]{2}{*}{ Mean } & \multirow[b]{2}{*}{$S D$} & \multirow[b]{2}{*}{ Constant } & \multicolumn{2}{|c|}{ Regression coefficient } & \multirow[b]{2}{*}{ Multiple $R$} & \multirow{2}{*}{$\begin{array}{l}\text { Standard } \\
\text { error }\end{array}$} & \multicolumn{2}{|c|}{ Correlation coefficients } \\
\hline & & & & $A g e^{2}$ & Height & & & Age & Height \\
\hline $\begin{array}{l}\text { FVC } \\
\text { FEV }\end{array}$ & $\begin{array}{l}2 \cdot 37 \\
2 \cdot 08\end{array}$ & $\begin{array}{l}0.36 \\
0.33\end{array}$ & $\begin{array}{l}-2.883 \\
-1.900\end{array}$ & - & $\begin{array}{l}0.035 \\
0.026\end{array}$ & $\begin{array}{l}0.50 \\
0.40\end{array}$ & 0.325 & 0.033 & $0.496^{\star \star}$ \\
\hline$\frac{\mathrm{FEV}_{1}}{\mathrm{FVC}} \%$ & $87 \cdot 53$ & $6 \cdot 17$ & $94 \cdot 917$ & -0.00734 & -0.011 & $0 \cdot 42$ & $5 \cdot 639$ & $-0.366^{\star \star}$ & -0.029 \\
\hline $\begin{array}{l}\text { FRC } \\
\text { RV } \\
\text { TLC }\end{array}$ & $\begin{array}{l}1.98 \\
1.06 \\
3.43\end{array}$ & $\begin{array}{l}0.37 \\
0.26 \\
0.45\end{array}$ & $\begin{array}{l}-2 \cdot 119 \\
-0.324 \\
-2.307\end{array}$ & $\begin{array}{l}0.00022 \\
0.00017 \\
0.00024\end{array}$ & $\begin{array}{l}0.026 \\
0.008 \\
0.036\end{array}$ & $\begin{array}{l}0.42 \\
0.28 \\
0.46\end{array}$ & $\begin{array}{l}0.340 \\
0 \cdot 256 \\
0 \cdot 404\end{array}$ & $\begin{array}{l}0.135 \\
0.177 \\
0.143\end{array}$ & $\begin{array}{l}0.388^{\star \star} \\
0 \cdot 153 \\
0.457^{\star \star}\end{array}$ \\
\hline$\frac{\text { RV }}{\text { TLC }} \%$ & $30 \cdot 65$ & 5.94 & $42 \cdot 377$ & 0.00355 & -0.095 & $0 \cdot 22$ & $5 \cdot 844$ & $0 \cdot 184$ & $-0 \cdot 165$ \\
\hline $\begin{array}{l}\text { VA } \\
\text { TLco } \\
\text { Kco } \\
\text { CTLco } \\
\text { CKco }\end{array}$ & $\begin{array}{l}3 \cdot 15 \\
6 \cdot 34 \\
2 \cdot 03 \\
7 \cdot 34 \\
2 \cdot 34\end{array}$ & $\begin{array}{l}0.46 \\
1 \cdot 10 \\
0 \cdot 30 \\
1 \cdot 21 \\
0.31\end{array}$ & $\begin{array}{r}-2.608 \\
2.076 \\
4.293 \\
0.832 \\
4.908\end{array}$ & $\begin{array}{l}- \\
-0.00068 \\
-0.00024 \\
-0.00113 \\
-0.00034\end{array}$ & $\begin{array}{r}0.038 \\
0.032 \\
-0.014 \\
0.049 \\
-0.015\end{array}$ & $\begin{array}{l}0.42 \\
0.26 \\
0.37 \\
0.38 \\
0.48\end{array}$ & $\begin{array}{l}0 \cdot 422 \\
1: 072 \\
0 \cdot 279 \\
1 \cdot 127 \\
0 \cdot 272\end{array}$ & $\begin{array}{l}-0.019 \\
-0.272^{\star} \\
-0.318^{\star} \\
-0.347^{\star \star} \\
-0.226\end{array}$ & $\begin{array}{c}0.416^{\star \star} \\
0.072 \\
-0.312^{\star} \\
0.144 \\
-0.128\end{array}$ \\
\hline
\end{tabular}

${ }^{\star} \mathrm{p}<0.01 ;{ }^{\star \star} \mathrm{p}<0.001$.

Abbreviations as in table 1 .

correlation between TLco and age, and between $\mathrm{KcO}$ and age and height.

As the addition of a dummy variable for smoking did not have any significant effect on any of the pulmonary function measurements except Kco and CKco, the coefficients for smoking were introduced into the prediction equations only for $\mathrm{KCO}$ and $\mathrm{CK}$ co measurements.

The multiple regression equations for men and women based on age ${ }^{2}$ and height are shown in tables 1 and 2. Predicted values are derived from these regression equations as follows:

Predicted value $=\mathrm{K}+\left(\mathrm{age}^{2}\right.$ in years $\times$ age $^{2}$ coefficient $)$ + (standing height in $\mathrm{cm} \times$ height coefficient),

where $\mathrm{K}$ is the constant. Smoking coefficients are added for $\mathrm{KcO}$ and $\mathrm{CK}$ co to derive the predicted values in smokers.

The predicted values of various pulmonary function measurements obtained from these regression equations for subjects of specified age (30 years) and height $(165 \mathrm{~cm}$ for men,
$155 \mathrm{~cm}$ for women) are compared with those from other studies in tables 3 and 4.

\section{Discussion}

Establishing regression equations to predict various measurements of normal lung function on a regional basis in a country like India, with wide variations in geography, climate, food habits, and ethnic groups, is important for the management of patients with various cardiopulmonary diseases. Results of comprehensive lung function studies in normal subjects are available for North and West Indian subjects. ${ }^{23610}$ There have not, however, been any comparable studies of lung function, including lung volumes and diffusing capacity measurements, in South Indians of Dravidian stock living in a tropical climate at sea level with rice as their staple food. Previous studies of ventilatory capacity in South Indians had shown that the subjects had lower values for ventilatory capacity and expiratory flow ${ }^{4511}$ than subjects from the Western world and North Indians.

Table 3 Predicted pulmonary function values from various studies in men of specified age (30 y) and height (165 cm)

\begin{tabular}{|c|c|c|c|c|c|c|c|c|c|c|}
\hline Location and reference & $F V C(l)$ & $F E V_{1}(l)$ & $R V(l)$ & $F R C(l)$ & $T L C(l)$ & $V A(l)$ & $\begin{array}{l}\text { TLCo } \\
\left(\begin{array}{l}\text { mmol } / \\
\mathrm{kPa} / \mathrm{min})\end{array}\right.\end{array}$ & $\begin{array}{l}\text { Kco } \\
(\operatorname{mmol} \mid \\
k P a / m i n / l)\end{array}$ & $\begin{array}{l}\text { CTLCo } \\
\left(\begin{array}{l}\text { mmol } \mid \\
\text { kPa/min })\end{array}\right.\end{array}$ & $\begin{array}{l}\text { CKco } \\
\left(\begin{array}{l}\text { momol } \mid \\
k P a / \min / l)\end{array}\right.\end{array}$ \\
\hline $\begin{array}{l}\text { Indians } \\
\text { Jain }^{2} \text { (N India) } \\
\text { Udwadia }^{6} \text { (W India) } \\
\text { Kamat }^{11} \text { (S India) } \\
\text { Vijayan (this study) }\end{array}$ & $\begin{array}{l}3 \cdot 95 \\
3 \cdot 54 \\
3 \cdot 34 \\
3 \cdot 37\end{array}$ & $\begin{array}{l}- \\
2 \cdot 80 \\
2 \cdot 84 \\
2 \cdot 92\end{array}$ & $\begin{array}{l}1.50 \\
1.36 \\
1.43\end{array}$ & $\begin{array}{l}2 \cdot 80 \\
2 \cdot 43 \\
\frac{-}{2 \cdot 62}\end{array}$ & $\begin{array}{l}5 \cdot 35 \\
4 \cdot 67 \\
\overline{4 \cdot 74}\end{array}$ & $\overline{-}$ & $\begin{array}{l}\overline{8 \cdot 60} \\
\overline{9 \cdot 51}\end{array}$ & $\frac{-}{\overline{2} \cdot 17}$ & $\frac{-}{\overline{-}}$ & $\frac{-}{2 \cdot 21}$ \\
\hline $\begin{array}{l}\text { Caucasions } \\
\text { Cotes }^{8} \\
\text { Goldman }^{13}\end{array}$ & $\begin{array}{l}4 \cdot 44 \\
4 \cdot 29\end{array}$ & $\begin{array}{l}3.67 \\
-\end{array}$ & $-\overline{1 \cdot 52}$ & $\overline{3 \cdot 30}$ & $\begin{array}{l}5 \cdot 87 \\
5 \cdot 89\end{array}$ & $\overline{-}$ & $10 \cdot 09$ & $1 \cdot 81$ & $\overline{-}$ & - \\
\hline $\begin{array}{l}\text { Chinese } \\
\text { DaCosta }^{16}\end{array}$ & $3 \cdot 68$ & $3 \cdot 11$ & $1 \cdot 41$ & 3.05 & $5 \cdot 05$ & - & - & - & - & - \\
\hline $\begin{array}{l}\text { Others } \\
\text { Weslcock }{ }^{1} \text { (New Guinea coast) } \\
\text { Miller }^{15}\end{array}$ & 3.59 & $3 \cdot 15$ & - & 一 & - & - & - & - & - & - \\
\hline $\begin{array}{l}\text { Guyanan Indians } \\
\text { Guyanan Negroes }\end{array}$ & $\begin{array}{l}3.47 \\
3.64\end{array}$ & $\begin{array}{l}2 \cdot 91 \\
3 \cdot 07\end{array}$ & - & - & $\overline{-}$ & $\overline{-}$ & - & $\overline{-}$ & - & - \\
\hline $\begin{array}{l}\text { Highlanders } \\
\text { Woolcock }^{1}\end{array}$ & 3.90 & $3 \cdot 34$ & - & $2 \cdot 86$ & $5 \cdot 13$ & - & - & - & - & - \\
\hline
\end{tabular}

Abbreviations as in table 1. 
Table 4 Predicted pulmonary function values from various studies in women of specified age ( $30 y$ ) and height (155 cm)

\begin{tabular}{|c|c|c|c|c|c|c|c|c|c|c|}
\hline Location and reference & $F V C(l)$ & $F E V_{1}(l)$ & $R V(l)$ & $F R C(l)$ & $T L C(l)$ & $V A(l)$ & $\begin{array}{l}\text { TLCO } \\
\text { (mmol } \mid \\
\text { kPa/min) }\end{array}$ & $\begin{array}{l}\text { KCO } \\
(\text { mmol } / \\
k P a / \min / l)\end{array}$ & $\begin{array}{l}\text { CTLCo } \\
\text { (mmol } \mid \\
\text { kPa/min) }\end{array}$ & $\begin{array}{l}\text { CKco } \\
(\text { mmol } \mid \\
k P a|\min | l)\end{array}$ \\
\hline \multicolumn{11}{|l|}{ Indian } \\
\hline Jain $^{3}$ (N India) & $2 \cdot 78$ & - & $1 \cdot 22$ & $2 \cdot 13$ & 3.95 & - & - & - & - & - \\
\hline Udwadia $^{6}$ (W India) & $2 \cdot 61$ & $2 \cdot 02$ & $1 \cdot 16$ & 1.92 & 3.55 & - & $6 \cdot 80$ & - & - & 一 \\
\hline $\operatorname{Kamat}^{11}$ (S India) & $2 \cdot 34$ & 1.89 & - & - & - & - & - & - & - & - \\
\hline Vijayan (this study) & $2 \cdot 54$ & $2 \cdot 13$ & $1 \cdot 07$ & $2 \cdot 11$ & 3.49 & $3 \cdot 28$ & $6 \cdot 42$ & 1.91 & $7 \cdot 41$ & $2 \cdot 28$ \\
\hline \multicolumn{11}{|l|}{ Caucasians } \\
\hline Goldman $^{13}$ & $3 \cdot 16$ & - & $1 \cdot 17$ & $2 \cdot 63$ & 4.52 & - & - & - & - & - \\
\hline Hall et $a l^{18}$ & $3 \cdot 48$ & $2 \cdot 81$ & $1 \cdot 28$ & $2 \cdot 92$ & $4 \cdot 77$ & - & $9 \cdot 00$ & - & - & - \\
\hline \multicolumn{11}{|l|}{ Chinese } \\
\hline $\mathrm{DaCosta}^{16}$ & $2 \cdot 70$ & $2 \cdot 33$ & $1 \cdot 18$ & 1.90 & 3.97 & - & 一 & 一 & - & - \\
\hline \multicolumn{11}{|l|}{ Others } \\
\hline Woolcock ${ }^{1}$ (New Guinea coast) & $2 \cdot 61$ & $2 \cdot 27$ & 一 & - & - & - & 一 & - & - & - \\
\hline \multicolumn{11}{|l|}{ Miller $^{15}$} \\
\hline New Guyanan Indians & $2 \cdot 71$ & $2 \cdot 17$ & - & - & - & 一 & - & - & - & - \\
\hline New Guyanan Negroes & $2 \cdot 81$ & $2 \cdot 30$ & 一 & 一 & 一 & - & - & - & - & - \\
\hline \multicolumn{11}{|l|}{ Highlanders } \\
\hline Woolcock $^{1}$ & $3 \cdot 07$ & $2 \cdot 53$ & - & $2 \cdot 49$ & $4 \cdot 42$ & - & - & - & - & - \\
\hline
\end{tabular}

Abbreviations as in table 1 .

The positive and strong correlations between various indices of lung size (FVC, FRC, TLC, and VA) and height in both sexes in this study are similar to those reported in previous studies. ${ }^{12611-13}$ There was no age related decline in FVC in either sex in this study but FEV showed an age related decline in men, though not in women. In a study of 250 non-smoking healthy Pakistanis from an area with extremely low levels of air pollution Ayub et al found that in men age made only a slight contribution to change in FVC and $\mathrm{FEV}_{1} \cdot{ }^{14}$ The absence of any age related decline in FVC has also been observed in North Indians. ${ }^{2}$ FVC, $\mathrm{FEV}_{1}$, and $\mathrm{FEV}_{1} / \mathrm{FVC} \%$ in both sexes in our study are similar to values reported by Udwadia et al in West Indians ${ }^{6}$ and by Kamat et al in South Indians. ${ }^{11}$ They are also similar to those of Guyanan Indians, ${ }^{15}$ coastal dwellers of New Guinea, ${ }^{1}$ and Chinese, ${ }^{16}$ but are lower than those reported from North India ${ }^{23}$ and from Western countries. ${ }^{12} 13$ 17-20

Static lung volumes (TLC and FRC) in both sexes were similar to those seen in West Indians, ${ }^{6}$ but lower than those of North Indians. ${ }^{23}$ Lung volumes are about $15-20 \%$ lower in South Indians than in Western subjects. ${ }^{13}{ }^{17}$ Age was associated with an increase in TLC in men but had a minimal effect in women. Our findings are similar to those of other studies from India ${ }^{26}$ and in highlanders from New Guinea. ${ }^{1}$ Earlier observations suggested that RV may not show ethnic variability ${ }^{8}$ and, in keeping with this, $R V$ in our study was similar to values reported from studies of Indian, ${ }^{26}$ Western, ${ }^{13}$ and Chinese subjects. ${ }^{16}$ The early closure of peripheral airways in subjects with small lungs may be responsible for the similar RV values in the various groups despite different lung volumes.

The single breath transfer factor (TLCO) in men in our study was similar to values seen in West Indians ${ }^{6}$ and similar to ${ }^{21}$ or slightly less $(6 \%)$ than European values. ${ }^{8}$ Though Tico values in South Indian and British men were similar, ${ }^{8}$ the British subjects had a higher alveolar volume and hence lower $\mathrm{Kco}$ values. Previous reports found no difference in Kco between the $\operatorname{sexes}^{223}$ and we may reasonably assume that the gas transfer per unit lung volume is similar in men and women. The fact that Kco was $10 \%$ lower in women in our study than in men may be due to the fact that more women $(23 \%)$ had a haemoglobin concentration below $10 \mathrm{~g} / \mathrm{dl}$, only two men having a concentration less than $11 \mathrm{~g} / \mathrm{dl}$. Kco values were similar in men and women after correction for haemoglobin concentration. The finding of similar TLCO values in men in the present study and in Western studies, despite 15-20\% lower values for lung volumes, points to the need for further study.

1 Woolcock JA, Colman MH, Blackburn CRB. Factors affecting normal values for ventilatory lung function. $A m R e v$ Respir Dis 1972;106:692-709.

2 Jain SK, Ramaiah TJ. Normal standards of pulmonary function tests for healthy Indian Men 15-40 years old. Comparison of different regression equations (prediction formulae). Indian J Med Res 1969;57:1453-66.

3 Jain SK, Ramaiah TJ. Influence of age, height and body surface area on lung functions in healthy women 15-40 surface area on lung functions in healthy

4 Milledge JB. Vital capacity and forced expiratory volume in South Indian men. Indian J Chest Dis 1965;7:95-105.

5 Kamat SR, Thiruvengadam KV, Rao TL. A study of pulmonary functions among Indians and assessment of the Wright's peak flow meter in relation to spirometry for field use. Am Rev Respir Dis 1967;96:707-16.

6 Udwadia FE, Sunavala JD, Shetye VM. Lung function studies in healthy Indian subjects. $J$ Ass Physicians India 1987;35:491-6.

7 Ferris BG, ed. Epidemiology standardisation project. Am Rev Respir Dis 1978;118(part 2):62-72.

8 Cotes JE. Lung function: assessment and applications in medicine. 3rd ed. Oxford: Blackwell, 1975:113-7, 228-59, 340-95.

9 Cotes JE, Dabbs JM, Elwood PC, Hall AM, McDonald A, Saunders MJ. Iron deficiency anemia: its effects on during ventilation and cardiac frequency during submaximal

10 Guleria JS, Sharma MP, Pande JN, Ramachandran K. Pulmonary diffusing capacity in normal Indian subjects. Pulmonary diffusing capacity in normal In

11 Kamat SR, Tyagi NK, Rashid SSA. Lung functions in Indian adult subjects. Lung India 1982;1:11-21. 
12 Grimby G, Soderholm B. Spirometric studies in norma subjects. III. Static lung volumes and maximum voluntary ventilation in adults with a note on physical fitness. Acta Med Scand 1963;173:199-206.

13 Goldman HI, Becklake MR. Respiratory function tests: Normal values at median altitudes and the prediction of normal results. Am Rev Tuberc 1959;79:457-67.

14 Ayub M, Zaidi SH, Burki NK. Spirometry and flow-volum curves in healthy normal Pakistanis. $\mathrm{Br} J$ Dis Ches 1987;81:35-44.

15 Miller GJ, Aschcroft MT, Swan AV, Beadnell HMSG. Ethnic variation in forced expiratory volume and forced vital capacity of African and Indian adults in Guyana. $\mathbf{A m}$ Rev Respir Dis 1970;102:979-81.

16 DaCosta JL Pulmonary function studies in healthy chinese Din to

17 Cotes JE, Rossiter CE, Higgins ITT, Gibon JC. Average normal values for the forced expiratory volume in white caucasian males. Br Med J 1966;i:1016-9.

18 Hall AM, Heywood C, Cotes JE. Lung function in healthy British Women. Thorax 1979;34:359-65.

19 Kory RC, Callahan R, Boren HG, Syner JC. The veterans administration army co-operative study of pulmonary 1961;30:243-58.

20 Ferris BG Jr, Anderson DO, Zickmantel R. Prediction values for screening tests of pulmonary function. Am Rev Respir Dis 1965;91:252-61.

21 Cotes JE, Malhotra MS. Differences in lung function between Indians and Europeans. J Physiol 1965;177:17-8 22 Burrows B, Kasik JE, Niden AH, Barclary WR. Clinical usefulness of the single-breath pulmonary diffusing capacity test. Am Rev Respir Dis 1961;84:789-806.

23 Bradley J, Bye C, Hayden SP, Hughes DTD. Normal values for transfer factor and transfer coefficients in healthy males and females. Respiration 1979;38:221-6. 